\title{
Using IRAP Markers for Analysis of Genetic Variability in Populations of Resource and Rare Species of Plants
}

\author{
S. V. Boronnikova ${ }^{a}$ and R. N. Kalendar ${ }^{b}$ \\ a The Perm' State University, Biological Faculty, Department of Botany and Genetics of Plants, Perm', 614990 Russia; \\ e-mail: SVBoronnikova@yandex.ru \\ ${ }^{b}$ University of Helsinki, Institute of Biotechnology, Helsinki, 00014 Finland; \\ e-mail: ruslan.kalendar@helsinki.fi \\ Received December 04, 2008
}

\begin{abstract}
Species-specific LTR retrotransposons were first cloned in five rare relic species of drug plants located in the Perm' region. Sequences of LTR retrotransposons were used for PCR analysis based on amplification of repeated sequences from LTR or other sites of retrotransposons (IRAP). Genetic diversity was studied in six populations of rare relic species of plants Adonis vernalis L. by means of the IRAP method; 125 polymorphic IRAP-markers were analyzed. Parameters for DNA polymorphism and genetic diversity of A. vernalis populations were determined.
\end{abstract}

DOI: $10.1134 / \mathrm{S} 1022795410010060$

\section{INTRODUCTION}

Mobile genetic elements are obligatory components of eukaryotic genome. Barbara McClintok established that the genome of maize contains many transposable elements [1]. DNA of mobile elements in Drosophila was isolated and cloned by teams of Russian researchers headed by G.P. Georgiev and V.A. Gvozdev in the Soviet Union and by D. Hogness in the United States [2]. Currently, many researchers have been extensively studying mobile elements of different types, including retrotransposons, mechanisms of their transposition, their role in the genome, and systems of genetic instability [3-5].

As an intermediate stage of the life cycle, retrotransposons copy their RNA by reverse transcription to obtain a DNA copy that integrates in host DNA with the aid of integrase [6, 7]. Sequences of retrotransposons carry regulatory sites (promoters) recognized by nuclear factors of transcription initiation for RNA synthesis with polymerases II and III. Most sequences in retrotransposons are inactivated due to mutations and transcribed only in part. Specific retrotransposons in various species may be completely inactive, rarely active, or permanently active [4]. In some cases, the number of retrotransposon copies constitutes up to $90 \%$ of the nuclear genome [6].

Sequences of LTR retrotransposons are employed to identify polymorphism of analyzed forms belonging to a single species by PCR-fingerprinting technique by IRAP, REMAP, and SSAP methods [8-10]. In AluPCR (SINE-PCR), the regions located between short retrotransposons without LTR-SINEs (Short Interspersed Elements) — are used [11, 12].
IRAP (Inter-Retrotransposon Amplified Polymorphism) is a method for amplification of genomic DNA between closely located sequences of retrotransposons $[8,9,13]$. The product of PCR amplification of genomic DNA is a stable genetic IRAP-marker. In this case, polymorphism is caused by a mutation in the site of binding with primer or by unique biological process (retrotransposition resulting from insertion of retrotransposon into a novel site of genomic DNA without a loss of the original site).

The aim of the present work was developing the IRAP method for five rare relic species of plants from the Perm' region by cloning sites of genomic DNA containing LTR retrotransposons and subsequent screening for the appropriate primers, using primers from retrotransposons for PCR-fingerprinting, and conducting genetic analysis of polymorphism in six populations of rare relic species $A$. vernalis.

\section{MATERIALS AND METHODS}

Five rare relic species of decorative and medicinal plants located in Perm' region became the object of this study: Adonis vernalis L. and Adonis sibirica Patrin ex Ledeb. from the family Ranunculaceae, Paeonia anomala L. from the family Paeoniacea, Adenophora lilifolia (L.)A.DC. from the family Campanulaceae, Digitalis grandiflora Mill. from the family Scrophulariaceae, with the category of threatened state $3(\mathrm{R})$, a rare species [14]. For analysis of DNA moleculargenetic polymorphism, leaves were collected from 30 randomly chosen plants of each species located 30$50 \mathrm{~m}$ apart. DNA was isolated using the method of A.M. Torres et al. [15] with minor modifications. An 
examination of population structure and moleculargenetic analysis of five rare plant species were conducted from 1994 to 2009 in the molecular-genetic laboratory of Department of Plant Botany and Genetics, Perm' State University. Cloning, analysis of DNA sequences, choosing LTR primers, and assessment of their effectiveness were made in the Plant Genomics Laboratory at the Institute of Biotechnology, University of Helsinki. Sequences of retrotransposons were amplified from genomic DNA by the method of retrotransposon universal primers [16]. A DNA fragment was extracted from agarose gel according to the protocol of QIAGEN, and DNA fragments were ligated to the pGEM-T (Promega) plasmid T-vector. Plasmid DNA was transformed into Escherichia coli cells of strain JM109. Cells with the plasmid carrying an insertion of foreign DNA fragment were detected through white-blue selection on a medium with ampicillin, XGal, and IPTG. Positive colonies were tested for the presence of cloned PCR products in the PCR reaction with universal pUC primers (forward and reverse M13 primers). DNA sequences were analyzed in a capillar ABI3700 sequencer (Applied Biosystems). Cloning of the entire retrotransposon sequence was conducted in inverted PCR with extension synthesis using closely located LTR-primers with divergent orientation. The amplification product contains both LTR sequences and the whole core sequence of the retrotransposon. Amplification was run at high temperature of annealing, in double-step PCR (denaturation at $95^{\circ} \mathrm{C}$ for $30 \mathrm{~s}$; primer annealing and synthesis simultaneously at $68^{\circ} \mathrm{C}$ for 4 min) during 15 cycles using Phusion DNA Polymerase (Finnzymes). Cloning of extended amplification products was conducted, as in the case of short PCR products, in the pGEM-T vector, the product of amplification being previously prepared for ligation by adding to blunt ends the dTs (each at the $3^{\prime}$ end) with $T a q$ polymerase. In accordance with the conserved regions of oppositely directed LTR retrotransposons, primers were developed by means of the FastPCR program [17]. For IRAP analysis of five rare species in Ural, 70 primers were synthesized in MWG Biotech AG.

For the approbation of identified IRAP-markers, a rare species A. vernalis was chosen, the most promising for the treatment of coronary heart diseases, which contains heart glycosides that have no cumulative effect and do not accumulate in the heart muscle [18]. We studied six $A$. vernalis populations located in the island part of Cungur forest-steppe at least $20 \mathrm{~km}$ apart. The most northern population (the second $A v 2$ ) is located on the Spass mountain in the Cungur district $45 \mathrm{~km}$ from the nearest population. The first $(A v 1)$ and third $(A v 3)$ populations are located in the northern part of Cungur forest-steppe within the Ordin oblast'. The fourth (Av4), fifth (Av5) and sixth (Av6) populations are encountered in the central region of the island territory of Cungur forest-steppe within the Oktyabr' oblast'.

RUSSIAN JOURNAL OF GENETICS Vol. 46 No. 12010
The reaction mixture $(25 \mu \mathrm{l})$ used for PCR, which was conducted by the IRAP method, contained $25 \mathrm{ng}$ of DNA, $1 \times$ PCR buffer ( $20 \mathrm{mM}$ Tris- $\mathrm{HCl}, \mathrm{pH} 8.8$, $\left.2 \mathrm{mM} \mathrm{MgSO} 4,10 \mathrm{mM} \mathrm{KCl}, 10 \mathrm{mM}\left(\mathrm{NH}_{4}\right)_{2} \mathrm{SO}_{4}\right)$, $0.2 \mu \mathrm{M}$ primer, $0.2 \mathrm{mM} \mathrm{dNTP}, 1$ unit of Taq polymerase FirePol (Solis BioDyne), $0.04 \mathrm{U}$ of $p f u$ polymerase (Fermentas), and $5 \mu \mathrm{l}$ of genomic DNA. Amplification was conducted using a PTC-100 thermal cycler (BioRad) or Master Cycler (Eppendorf) and $0.2-\mathrm{ml}$ tubes or 96-well plates. The DNA amplification program consisted of the following cycles: preliminary denaturation at $95^{\circ} \mathrm{C}$ for $3 \mathrm{~min} ; 32$ cycles at $95^{\circ} \mathrm{C}$ for $20 \mathrm{~s}$; annealing at $60^{\circ} \mathrm{C}$ for $1 \mathrm{~min}$; and at $68^{\circ} \mathrm{C}$ for $1 \mathrm{~min}$. The terminating cycle of elongation lasted $5 \mathrm{~min}$ at $68^{\circ} \mathrm{C}$. The annealing temperature varied from 55 to $68^{\circ} \mathrm{C}$, depending on $\mathrm{G} / \mathrm{C}$ composition of primers. Amplification products of PCR were fractionated by electrophoresis in a $1.6 \%$ agarose gel (RESolute Wide Range, BIOZym) and visualized using ethidium bromide. Gels were scanned at University of Helsinki in a FLA-5100 (Fuji) scanner or at Perm' State University in a system Gel-DocXRW (Bio-Rad). In order to determine lengths of DNA fragments, molecular marker $100 \mathrm{bp}+1.5+3 \mathrm{~Kb}$ DNA ladder (Sibenzim$\mathrm{M}$, Moscow) was used. Lengths of fragments were determined by means of the Quantity One computer program in the system Gel Doc XR (Bio-Rad). The effectivity of detecting DNA polymorphism was estimated for five examined species according to a $1: 5$ scale: from low (1) to high (5). To describe the genetic structure of population subgroups, the following parameters were used: an expected proportion of heterozygous genotypes $\left(H_{\mathrm{T}}\right)$ in the entire population as a measure of general gene diversity; the expected proportion of heterozygous genotypes $H_{\mathrm{S}}$ in subpopulations as a measure of its intrapopulation diversity a proportion of interpopulation genetic diversity in the general diversity, or an indication of subgroups in populations $\left(G_{\mathrm{ST}}\right)$ [19]. Computer-aided analysis of these data was conducted by means of a POPGENE1.31 software package and by specific macros GenA1Ex6 for MS-Excel.

\section{RESULTS}

In this work, for amplification of retrotransposon sequences from genomic DNA, we employed (Fig. 1a) the original method of retrotransposon universal primers [16] including amplification of tRNA primerbinding sites (PBS) identified in the core portion of all retrotransposons. The sequence of PBS region is positioned immediately following several nucleotides after the first LTR. We identified putative LTR regions and, using the method of DNA sequence alignment, revealed conserved regions on which screening for conserved LTR primers had been conducted. The complete sequence of LTR retrotransposon was determined through inverted amplification with primers specific for the detected LTR region. Some nucleotide 

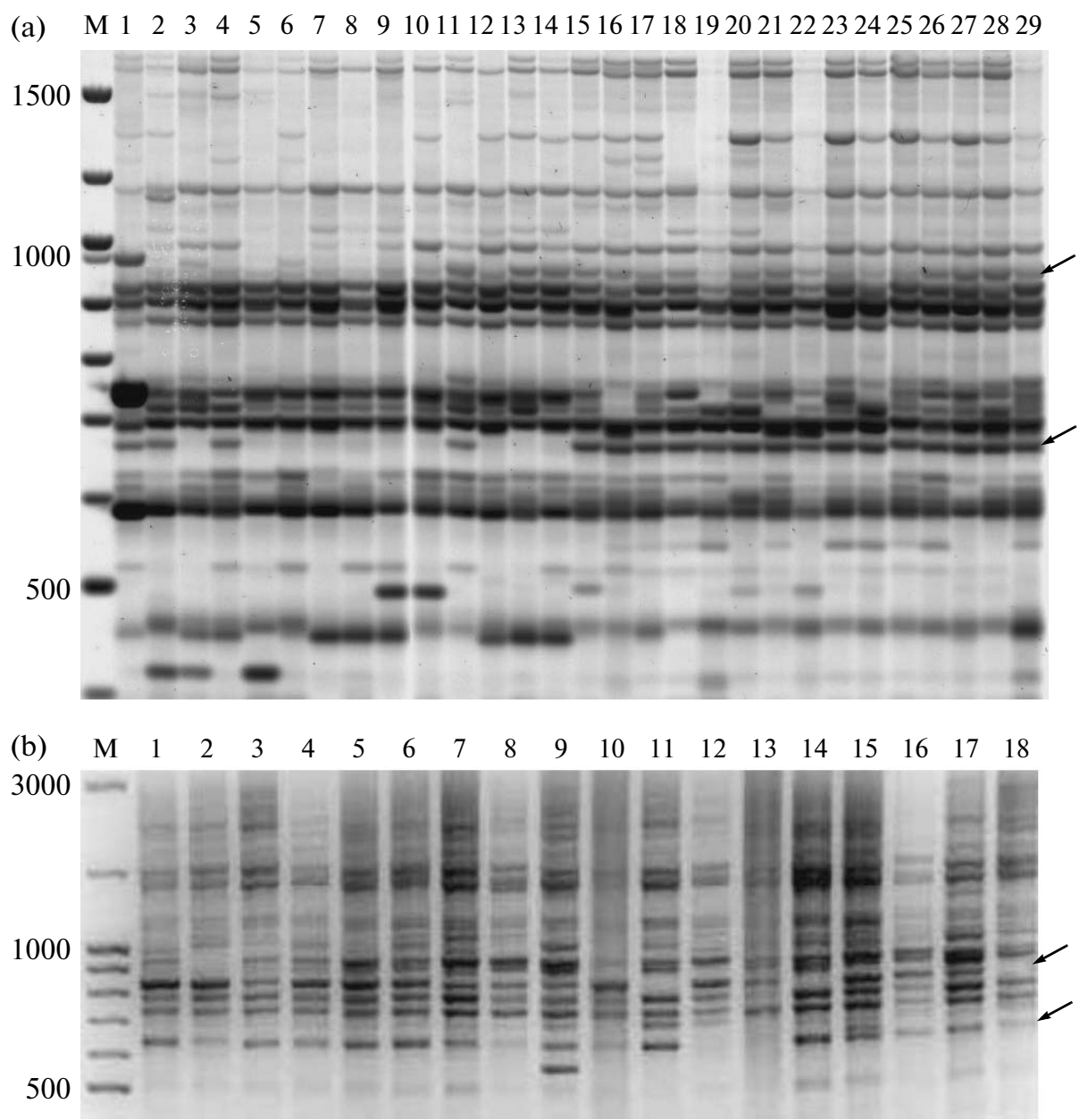

Fig. 1. IRAP spectra of $A$. vernalis: (a), Av5 populations with primer 2079 (5'-AGGTGGGCGCCA-3') as a result of using the method of retrotransposon universal primers; (b), Av6 populations with primer 2204. Ordinals indicate numbers of samples; M, molecular marker; arrows mark several polymorphic DNA fragments. Some of the spectra are presented.

sequences of fragments of LTR retrotransposons for the examined plant species located in the territory of Perm' were registered in the database NCBI and assigned the accession nos. EF191000-F191012 (http://www.ncbi.nlm.nih.gov/).

For IRAP analysis of five rare relic plant species, 70 LTR primers [20] for putative LTR sequences were chosen. Each primer was analyzed separately in PCR (IRAP) with genomic DNA of examined species. As a result, effective primers were detected (Table 1), and their species affiliation was determined.

Molecular-genetic analysis of six A. vernalis populations was conducted with five most informative LTR primers (Table 2). Analyzing PCR-amplified DNA fragments with five LTR-primers in six studied $A$. vernalis populations, we found 127 DNA fragments, 118 of which were polymorphic. The number of amplified DNA fragments varied in the total plant sample from 19 (2202) to 31 (2197), depending on the primer. In IRAP analysis, one primer, on average, is responsible for initiating the synthesis of 25 DNA fragments
A. vernalis. The number of polymorphic fragments varied in the total $A$. vernalis plant sample from 17 to 30 , their sizes amounting to $190-2500 \mathrm{bp}$ (Fig. 1b; Table 2). Results obtained in analysis of DNA polymorphism, which was conducted in two geographically distant laboratories, are identical.

A proportion of polymorphic loci $\left(P_{95}\right)$ in the total sample varied from 86 to $96 \%$, depending on the LTR primer and amounted to $93 \%$ per sample (Table 2 ). The polymorphism level of amplified fragments of A. vernalis DNA obtained in PCR with five LTR primers varied from $54 \%$ in $A v 4$ to $77 \%$ in $A v 5$ and $A v 6$.

The expected heterozygosity at loci $\left(H_{\mathrm{E}}\right)$ in the total sample of $A$. vernalis amounted to 0.291 . Av5 exhibits the highest parameter $\left(H_{\mathrm{E}}=0.270\right)$, whereas the lowest value was observed in $A v 1\left(\mathrm{H}_{\mathrm{E}}=0.177\right)$ (Fig. 2). The absolute number of alleles per locus $\left(n_{\mathrm{a}}\right)$ (in our case, per DNA fragment) in the total sample of $A$. vernalis constituted 1.992, and the effective number of alleles per locus $\left(n_{\mathrm{e}}\right)$ amounted to 1.497. Both 
Table 1. Primers from LTR sequences of retrotransposons in examined species

\begin{tabular}{|c|c|c|c|c|c|c|}
\hline No. & $\begin{array}{l}\text { Sequences of LTR primers } \\
\qquad\left(5^{\prime} \longrightarrow 3^{\prime}\right)\end{array}$ & Source of LTR & $\begin{array}{l}\text { Adonis vernalis, } \\
\text { A. sibirica }\end{array}$ & $\begin{array}{c}\text { Digitalis } \\
\text { grandiflora }\end{array}$ & $\begin{array}{c}\text { Paeonia } \\
\text { anomala }\end{array}$ & $\begin{array}{l}\text { Adenophora } \\
\quad \text { lilifolia }\end{array}$ \\
\hline 2156 & ACAAGTTGTCCAAGGGCTTTCCTC & Adenophora lilifolia & 2 & 1 & & 5 \\
\hline 2157 & AGGTGGGCGCCAAACTGTTTTGG & Adenophora lilifolia & 2 & & & 4 \\
\hline 2194 & CTACTGATCATGATGCCGCTG & Adenophora lilifolia & 1 & & & 2 \\
\hline 2196 & CCGGCGAGTTCAGCATGTCG & Adenophora lilifolia & $\mathbf{1}$ & & & 4 \\
\hline 2175 & TTAGACCCGGAACCGCCGTG & Adonis sibirica & 4 & 1 & 2 & \\
\hline 2209 & AATTGGTCAAGAGTGGAGAGGAC & Adonis sibirica & 2 & & & 1 \\
\hline 2211 & GTTGGAGTGTATAGTCCCACATCG & Adonis sibirica & 3 & & & \\
\hline 2149 & GTAGTTTCGGGTTCGGAATTGCA & Adonis vernalis & 2 & $\mathbf{1}$ & & \\
\hline 2197 & GAAGTACCGATTTACTTCCGTGTA & Adonis vernalis & 4 & & & \\
\hline 2198 & ATCCTTCGCGTAGATCAAGCGCCA & Adonis vernalis & 4 & & & \\
\hline 2200 & ATGTGACAGTCGACTAACCAC & Adonis vernalis & 3 & & & \\
\hline 2201 & CCTAGGTGGTTAGTCGACTGTCAC & Adonis vernalis & 5 & & & \\
\hline 2202 & TGGCGCTTGATCTACGCGAAGGA & Adonis vernalis & 5 & & & \\
\hline 2203 & ATCCCACAACTTGGACGTTTGCTG & Adonis vernalis & 3 & & & 1 \\
\hline 2204 & AACTTGATCCAGATCATCTCC & Adonis vernalis & 4 & & & \\
\hline 2155 & AGCTTGATATCCCGCCCCGGTCAA & Digitalis grandiflora & & 5 & & 1 \\
\hline 2158 & CCATCGGGTCCGGGCAATATCG & Digitalis grandiflora & & 4 & & 1 \\
\hline 2159 & AGCGAATCAACAGGGGCTGCCCGA & Digitalis grandiflora & 2 & 3 & & 3 \\
\hline 2183 & TTGCAAATACCAGTGGCGGGTCGT & Digitalis grandiflora & 2 & 2 & & \\
\hline 2185 & AATTCCACAACCGCTAGTGGCG & Digitalis grandiflora & & 4 & & 1 \\
\hline 2186 & CGGTTTAGAACGCCACAAATGG & Digitalis grandiflora & & 4 & & \\
\hline 2152 & AGTGAGCATGGGAGCGGACAAGC & Paeonia anomala & 2 & & 4 & 4 \\
\hline 2153 & ATCTTTTGAGACCAAGCTTCCGTC & Paeonia anomala & & & 2 & 1 \\
\hline 2164 & GTGTCTCCCAGTCAAAGCGGACAA & Paeonia anomala & & 3 & & \\
\hline 2165 & GTTCTCCTTACTAGCCGATGTGGGA & Paeonia anomala & & 1 & & 2 \\
\hline 2187 & TGATTCCTAAGCATGGTACAAC & Paeonia anomala & & & & 3 \\
\hline 2216 & TACTATGTGAACGGGTCTGGGCTG & Paeonia anomala & & 1 & 4 & 3 \\
\hline
\end{tabular}

Note: Primers with low efficiency are not presented (only 1 or 2 ).

parameters were maximal in $\operatorname{Av} 5\left(n_{\mathrm{a}}=1.859, n_{\mathrm{e}}=\right.$ $1.445)$ and minimal in $A v 1\left(n_{\mathrm{a}}=1.617, n_{\mathrm{e}}=1.281\right)$.

The expected proportion of heterozygous genotypes per subdivided population of $A$. vernalis $\left(H_{\mathrm{T}}\right)$ inferred from polymorphism of PCR fragments in the overall population is equal to 0.305 , being 0.225 in subpopulations $\left(H_{\mathrm{S}}\right)$. Thus, an expected proportion of heterozygous genotypes in $A$. vernalis subpopulations is lower than that in the overall population. The population subdivision coefficient $\left(G_{\mathrm{ST}}\right)$ indicates that the interpopulation component of genetic diversity in A. vernalis. is equal to $26 \%$. The examined populations of rare relic species of $A$. vernalis plants are strongly differentiated.

RUSSIAN JOURNAL OF GENETICS Vol. $46 \quad$ No. $1 \quad 2010$

\section{DISCUSSION}

The sequences of retrotransposons in eukaryotic genomes are interesting from the viewpoint of evolution. In some cases, the total number of all retrotransposons (with and without LTR) can amount to $90 \%$ of the nuclear genome of plants and animals [6, 7]. Retrotransposons were successful as applied to genetic analysis with the employment of various fingerprinting techniques: hybridization on a membranes or in PCR $[8,10]$. When there are sequenced retrotransposons, it is possible to select primers for their most conserved sites, which can be used for PCR fingerprinting. In this connection, a search for retrotransposon sequences is necessary and perspective for new species. Sequences 
Table 2. Analysis of DNA polymorphsm in A. vernalis L. populations by the IRAP method

\begin{tabular}{|c|c|c|c|c|c|c|c|c|c|c|}
\hline \multirow{2}{*}{$\begin{array}{l}\text { IRAP } \\
\text { primers }\end{array}$} & \multirow{2}{*}{$\begin{array}{l}\text { Nucleotide sequence } \\
\qquad\left(5^{\prime} \longrightarrow 3^{\prime}\right)\end{array}$} & \multirow{2}{*}{$\begin{array}{l}\text { Sizes of DNA } \\
\text { fragments, bp }\end{array}$} & \multicolumn{6}{|c|}{$\begin{array}{l}\text { Number (frequency) of polymorphic } \\
\text { fragments in populations }\end{array}$} & \multirow{2}{*}{$\begin{array}{c}\text { Number of } \\
\text { registered DNA } \\
\text { fragments }\end{array}$} & \multirow{2}{*}{$\begin{array}{l}\text { Number (frequen- } \\
\text { cy) of polymorphic } \\
\text { DNA fragments }\end{array}$} \\
\hline & & & $A v 1$ & $A v 2$ & $A v 3$ & $A v 4$ & $A v 5$ & $A v 6$ & & \\
\hline 2175 & $\begin{array}{l}\text { TTAGACCCG- } \\
\text { GAACCGCCGTG }\end{array}$ & $190-2400$ & $\begin{array}{c}16 \\
0.695\end{array}$ & $\begin{array}{c}13 \\
0.542\end{array}$ & $\begin{array}{c}18 \\
0.783\end{array}$ & $\begin{array}{c}18 \\
0.783\end{array}$ & $\begin{array}{c}19 \\
0.792\end{array}$ & $\begin{array}{c}22 \\
0.917\end{array}$ & 24 & $\begin{array}{c}23 \\
0.958\end{array}$ \\
\hline 2198 & $\begin{array}{l}\text { ATCCTTCGCGTA- } \\
\text { GATCAAGCGCCA }\end{array}$ & $310-2470$ & $\begin{array}{c}18 \\
0.600\end{array}$ & $\begin{array}{c}16 \\
0.533\end{array}$ & $\begin{array}{c}18 \\
0.600\end{array}$ & $\begin{array}{c}22 \\
0.733\end{array}$ & $\begin{array}{c}18 \\
0.600\end{array}$ & $\begin{array}{c}21 \\
0.700\end{array}$ & 30 & $\begin{array}{c}26 \\
0.867\end{array}$ \\
\hline 2202 & $\begin{array}{l}\text { TGGCGCTTGATC- } \\
\text { TACGCGAAGGA }\end{array}$ & $300-1650$ & $\begin{array}{c}11 \\
0.579\end{array}$ & $\begin{array}{c}11 \\
0.579\end{array}$ & $\begin{array}{c}11 \\
0.579\end{array}$ & $\begin{array}{c}10 \\
0.526\end{array}$ & $\begin{array}{c}14 \\
0.737\end{array}$ & $\begin{array}{c}16 \\
0.842\end{array}$ & 19 & $\begin{array}{c}17 \\
0.895\end{array}$ \\
\hline 2200 & $\begin{array}{l}\text { ATGTGACAGTC- } \\
\text { GACTAACCAC }\end{array}$ & $360-2500$ & $\begin{array}{c}16 \\
0.696\end{array}$ & $\begin{array}{c}14 \\
0.609\end{array}$ & $\begin{array}{c}13 \\
0.565\end{array}$ & $\begin{array}{c}7 \\
0.304\end{array}$ & $\begin{array}{c}16 \\
0.696\end{array}$ & $\begin{array}{c}18 \\
0.783\end{array}$ & 23 & $\begin{array}{c}22 \\
0.956\end{array}$ \\
\hline 2197 & $\begin{array}{l}\text { GAAGTACCGATT- } \\
\text { TACTTCCGTGTA }\end{array}$ & $340-2430$ & $\begin{array}{c}13 \\
0.419\end{array}$ & $\begin{array}{c}28 \\
0.983\end{array}$ & $\begin{array}{c}20 \\
0.645\end{array}$ & $\begin{array}{c}12 \\
0.387\end{array}$ & $\begin{array}{c}31 \\
0.969\end{array}$ & $\begin{array}{c}21 \\
0.677\end{array}$ & 31 & $\begin{array}{c}30 \\
0.68\end{array}$ \\
\hline Total & & & $\begin{array}{c}74 \\
0.583\end{array}$ & $\begin{array}{c}82 \\
0.646\end{array}$ & $\begin{array}{c}80 \\
0.630\end{array}$ & $\begin{array}{c}69 \\
0.543\end{array}$ & $\begin{array}{c}98 \\
0.772\end{array}$ & $\begin{array}{c}98 \\
0.772\end{array}$ & 127 & $\begin{array}{c}118 \\
0.929\end{array}$ \\
\hline
\end{tabular}

Note: Designations of populations are given in the text.

of retrotransposons can be obtained with various approaches; for instance, by amplification of reverse transcriptase gene and subsequent cloning of the closely located LTR site. Another method is based on amplification of genomic DNA with a single primer (or combined with the other primer) complementary to PBS region. PCR fragments amplified by this method contain inverted PBS sequences immediately followed by putative LTR sequences [16]. The sequences of various retrotransposons in the chromosomal DNA undergo clustering and interact with each other; therefore, the probability that LTR fragment may be found upon amplification with primers complementary to PBS region is rather high [16].

Analysis of 70 developed LTR primers revealed that they are species-specific primers, i.e., fingerprinting is observed only for the specific primer, from which the retrotransposon was isolated. In related species,

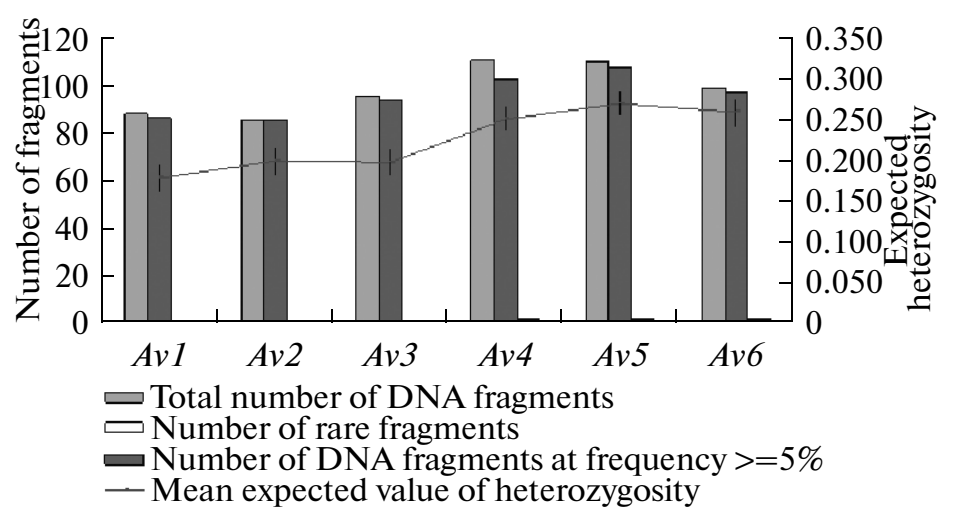

Fig. 2. Parameters of genetic diversity in six populations of $A$. vernalis. 
sequences of identical LTR retrotransposons differ in accordance with the degree of relatedness among analyzed species [16]. In this respect, LTR primers developed in related species for one of them can be used to amplify DNA of other species. Many more retrotransposons have been detected in genomes of plants and animals, and therefore, the IRAP method has high potential for providing information (the number of loci and their polymorphism) [21, 22]. New retrotranspositions in the host genome may, depending on their location, lead to changes in gene activity, induce chromosomal alterations, dynamically affect chromosome sizes, and also promote recombination of chromosomes upon crossing over [4].

Molecular-genetic analysis of DNA conducted by means of the IRAP method revealrd that the first $(A v I)$ population of $A$. vernalis located in the Ordin oblast' exhibits the lowest values of genetic diversity $\left(P_{95}=\right.$ $\left.58 \% ; H_{\mathrm{E}}=0.177 ; n_{\mathrm{e}}=1.281\right)$, whereas the highest parameters were observed in $A v 5$ located in the Oktyabr' oblast' $\left(P_{95}=77 \% ; H_{\mathrm{E}}=0.270 ; n_{\mathrm{e}}=1.445\right)$.

PCR method, in which primers from highly repeated elements (such as retrotransposons) are used, allows effective detection of intraspecific polymorphism. With the employment of IRAP technique, molecular-genetic analysis was conducted, genetic diversity of rare relic plant species [23-25] as well as widely distributed resource species [26] was studied, and a method of molecular-genetic identification and classification of gene pools in rare and defence-requiring plant species was designed [24].

Thus, the use of DNA-fingerprinting technique developed on the basis of sequences of retrotransposons proved successful for the evaluation of intraand interpopulation genetic diversity of rare plant species and for characterization of the state of their gene pools.

\section{ACKNOWLEDGMENTS}

This work was supported by the Russian Foundation for Basic Research (grant RFBRa_ural no. 0704-96032).

\section{REFERENCES}

1. McClintok, B., Controlling Elements and the Gene, Cold Spring Harbor Symp. Quant. Biol., 1956, vol. 21, pp. 197-216.

2. Ilyin, Y.V., Tchurikov, N.A., Ananiev, E.V., et al., Studies on the DNA Fragments and Adjacent Sequences, Cold Spring Harbor Symp. Quant. Biol., 1978, vol. 42, pp. 959-969.

3. Lyubomirskaya, N.V. and Il'in, Yu.V., Mobile Genetic Elements of Eukaryotes: Past, Present, Future, Mol. Biol. (Moscow), 1999, vol. 33, no. 6, pp. 958-968.

4. Kalendar, R., Tanskanen, J., Immonen, S., et al., Genome Evolution of Wild Barley (Hordeum spontaneum) by BARE-1 Retrotransposon Dynamics in Response to
Sharp Microclimatic Divergence, Proc. Natl. Acad. Sci. USA, 2000, vol. 97, no. 12, pp. 6603-6607.

5. Evgen'ev, M.B., Mobile Elements and Genome Evolution, Mol. Biol. (Moscow), 2007, vol. 41, no. 2, pp. 234-245.

6. Kumar, A. and Bennetzen, J., Plant Retrotransposons, Annu. Rev. Genet., 1999, vol. 33, pp. 479-532.

7. Wicker, T., Sabot, F., Hua-Van, A., et al., A Unified Classification System for Eukaryotic Transposable Elements, Nat. Rev. Genet., 2007, no. 8, pp. 973-982.

8. Kalendar, R., Grob, T., Regina, M., et al., IRAP and REMAP: Two New Retrotransposon-Based DNA Fingerprinting Techniques, Theor. Appl. Genet., 1999, vol. 98, pp. 704-711.

9. Kalendar, R. and Schulman, A.H., IRAP and REMAP for Retrotransposon-Based Genotyping and Fingerprinting, Nat. Protocols, 2006, vol. 1, no. 5, pp. 2478-2484.

10. Leigh, F., Kalendar, R., Lea, V., et al., Comparison of the Utility of Barley Retrotransposon Families for Genetic Analysis by Molecular Marker Techniques, Mol. Gen. Genomics, 2003, vol. 269, no. 3, pp. 464-474.

11. Bannikova, A.A., Matveev, V.A., and Kramerov, D.A., Using Inter-SINE PCR to Study Mammalian Phylogeny, Russ. J. Genet., 2002, vol. 38, no. 6, pp. 714-724.

12. Ryabinina, N.L., Bannikova, A.A., Sheremet'eva, V.A., et al., Analysis of DNA of Higher Primates Using Inter-SINE PCR, Russ. J. Genet., 2008, vol. 44, no. 3, pp. 266-272.

13. Kalendar, R.N. and Glazko, V.I., Types of Molecular Genetic Markers and Their Application, Fiziol. Biokhim. Kulturnyh Rasteniy, 2002, vol. 34, no. 4, pp. 279-296.

14. Krasnaya kniga Permskogo kraya (Red Book of Perm Krai), Shepel', A.I., Ed., Perm: Knizhnyi mir, 2008.

15. Torres, A.M., Weeden, N.F., and Martin, A., Linkage among Isozyme, RFLP and RAPD Markers in Vicia faba, Theor. Appl. Genet., 1993, vol. 5, pp. 937-945.

16. Kalendar, R., Tanskanen, J., Antonius-Klemola, K., et al., Cassandra Retrotransposons Carry Independently Transcribed 5S RNA, Proc. Natl. Acad. Sci. USA, 2008, vol. 105, no. 15, pp. 5833-5838.

17. Kalendar, R., Lee, D., and Schulman, A.H., FastPCR Software for PCR Primer and Probe Design and Repeat Search, Genes Genomes Genomics, 2009, vol. 3, no. 1, http://www.biocenter.helsinki.fi/bi/programs/fastper.htm.

18. Poshkurlat, A.P., Rod goritsvet-Adonis L.: Sistematika, rasprostranenie, biologiya (Genus Adonis: Systematics, Distribution, Biology), Moscow: Nauka/Interperiodika, 2000.

19. Nei, M., Molecular Population Genetics and Evolution, Amsterdam, 1975.

20. Kalendar, R.N. and Boronnikova, S.V., Molecular Genetic Polymorphism of Natural Populations of Ural Rare Plant Species Using Retrotransposons, Biotekhnologiya: sostoyanie i perspektivy razvitiya (Biotechnology: Current State and Perspectives of Development), Proc. 4th Moscow Int. Congress, Moscow: Ekspobiokhim-tekhnologii, 2007, part 2, p. 121.

21. Boyko, E., Kalendar, R., Korzun, V., et al., A HighDensity Cytogenetic Map of the Aegilops tauschii 
Genome Incorporating Retrotransposons and Defense Related Genes: Insights into Cereal Chromosome Structure and Function, Plant Mol. Biol., 2002, vol. 48, pp. 767-790.

22. Baumel, A., Ainouch, M., Kalendar, R., et al., Retrotransposons and Genomic Stability in Populations of the Young Allopolyploid Species Spartina anglica Hubard (Poaceae), Mol. Biol. Evol., 2002, vol. 19, no. 8, pp. $1218-1227$.

23. Kokaeva, Z.G., Boronnikova, S.V., Tikhomirova, N.N., et al., Genetic Diversity Analysis of Population Systems of Rare and Resource Plant Species, Biotekhnologiyaokhrane okruzhayushchei sredy (Biotechnology to Environment Conservation), Proc. 4th Int. Sci. Conf., in Dokl. MOIP, Moscow, 2006, pp. 75-79.
24. Boronnikova, S.V., Molekulyarno-geneticheskaya identifikatsiya i pasportizatsiya redkikh i nakhodyashchikhsya pod ugrozoi unichtozheniya vidov rastenii (Molecular Genetic Identification and Certification of Rare and Endangered Plant Species), Perm: Perm Univ., 2008.

25. Boronnikova, S.V., Genetic Certification of Population of Rare Plant Species of the Genus Adonis Using ISSRand IRAP-Markers, Izv. Mosk. S-kh. Akad., 2009, no. 1, pp. 83-89.

26. Boronnikova, S.V., Svetlakova, T.N., and Boboshina, I.V., Genetic Polymorphism Study of Populus tremula L. Using ISSR- and IRAP-Markers, Agrarnaya Rossiya, 2009, no. 2, pp. 20-22. 